only a flow gain of $2 \cdot 5$, whereas the wall reattachment device has a flow gain of about 20. The total response time is about the same for both devices. The momentum device allows only a very small maximum control line resistance of about 0.8 , whereas the corresponding maximum one for the wall reattachment device is around 3 . The momentum device allows no 'fan out'. A further disadvantage of the pure momentum device is the fact that it has a tendency to become unstable at high receiver loads, furthermore the control flow has to be kept constant within small limits, whereas no restrictions exist for the wall reattachment device because the walls guide the main jet.

\title{
References
}

1) R. J. Reilly and F. A. Moyniham, Notes on a Proportional Fluid Amplifier. (Same as Ref. 6).

2) E. M. Dexter, An Analog Pure Fluid Amplitier. (Same as Ref. 6).

3) R. A. Comparin, A. E. Mitchell and H. R. MÜLler, Qualitative und quantitative Aspekte des Grenzschichtverstärkers, ZAMP 13, (1962).

4) A. MÉTral and F. Ferner, Sur un phénomène de déviation des veines fluides et ses applications (Effet Coanda), Proc. Fifth Int. Congress Appl. Mech., 1938, p. 456.

5) C. Bourgue and B. G. Newman, Reattachement of a Two-dimensional Incompressible Jet to an Adjacent Flat Plate, Aeron. Quart. 11, August 1960, p. 201.

6) R. A. Comparin, H. H. Glättri, A. E. Mitchell and H. R. Müller, On the Limitations and Special Effects in Fluid Jet Amplifiers, ASME Symposium on Fluid Jet Control Devices, 1962, Winter Annual Meeting.

7) M. L. Albertson, Y. B. Day, R. A. Jensen, The Diffusion of Submerged Jets, Transactions of Amer. Society of Civil Engineers, 175, 1950.

\section{International Federation for Information Processing (IFIP)}

Der IFIP-Kongress 65 wird in New York vom 24. bis 29. Mai 1965 stattfinden und wird alle Aspekte der Datenverarbeitung umfassen. Gleichzeitig wird die INTERDATA 65 Ausstellung mit Datenverarbeitungsmaschinen - durchgeführt.

A. P. SPEISER

\section{International Conference on Electron and Ion Beam Science and Technology, Toronto 1964}

The Electrochemical Society of the U.S.A., through its Electrothermics and Metallurgy Division, announces that it will sponsor, jointly with the Metallurgical Society of Aime, the first international conference on the subject of Electron and Ion Beam Science and Technology. This Conference will be held in Toronto (Canada), at the Royal York Hotel, on May 3-7, 1964.

For further information, please write to the Chairman of the Conference Committee, Dr. R. Bakish, Electronics and Alloys Inc., Ridgefield, New Jersey, U.S.A. E. B. BAS

\section{International Symposium on Quasi-Optics, New York 1964}

This Symposium, to be held in New York City, June 8-10, will be concerned with electromagnetic phenomena and techniques at wavelengths whose scale is small compared to guiding or perturbing structures. This operating range comprises, for example, lowfrequency propagation and diffraction in the earth-ionosphere waveguide as well as 